\title{
Detection of Squamous Cell Carcinoma Foci in a Patient with Dystrophic Epidermolysis Bullosa in ${ }^{18} \mathrm{~F}-\mathrm{FDG}$ PET/CT
}

\author{
Distrofik Epidermolizis Bülloza Tanısı Alan Bir Olguda Skuamöz Hücreli Karsinom Odağının \\ ${ }^{18}$ F-FDG PET/BT Yöntemi ile Saptanması
}

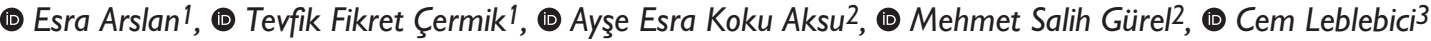 \\ IUniversity of Health Sciences, Istanbul Training and Research Hospital, Clinic of Nuclear Medicine, Istanbul, Turkey \\ 2University of Health Sciences, Istanbul Training and Research Hospital, Clinic of Dermatology, Istanbul, Turkey \\ 3 University of Health Sciences, Istanbul Training and Research Hospital, Clinic of Pathology, Istanbul, Turkey
}

\begin{abstract}
Dystrophic epidermolysis bullosa (DEB) is a rare, inherited skin fragility disorder characterized by blister formation in the sublamina densa. DEB is associated with aggressive squamous cell carcinoma (SCC) that has increased risk of metastases and poor prognosis. A 41-year-old woman with DEB underwent ${ }^{18}$-fluoro-2-deoxy-glucose positron emission tomography/computed tomography ( ${ }^{18 F}$-FDG PET/BT). PET/CT showed increased ${ }^{18} \mathrm{~F}-\mathrm{FDG}$ uptakes in multifocal cutaneous lesions in both lower extremities. The patient was diagnosed with SCC via skin biopsy from the left lateral lower thigh. Ten months later, PET/CT showed increased FDG uptakes in the primary tumor area as well as the left inguinal and left supraclavicular lymph node regions. ${ }^{18} \mathrm{~F}-\mathrm{FDG}$ PET/CT seems to be useful for re-staging and planning appropriate therapeutic strategy in DEB-patients with SCC.

Keywords: ${ }^{18} \mathrm{~F}-\mathrm{FDG}$ PET/CT, dystrophic epidermolysis bullosa, squamous cell carcinoma
\end{abstract}

\section{Öz}

Distrofik epidermolizis bülloza (DEB), sublamina densada veziküler ve yaygın bül oluşumu ile karakterize nadir görülen kalıtsal bir deri frajilite bozukluğudur. DEB bilhassa artmış metastaz riski ve kötü prognostik özellikler gösteren agresif skuamöz hücreli karsinom (SHK) oluşumu ile ilişkilendirilmiştir. DEB tanısı konulan 41 yaşındaki kadın olgu ${ }^{18} \mathrm{~F}$-floro-2-deoksi-glukoz pozitron emisyon tomografisi/bilgisayarlı tomografi ( ${ }^{18} \mathrm{~F}$-FDG PET/BT) taraması ile deri malignitesi açısından incelenmiştir. PET/BT taraması ile her iki alt ekstremitede multifokal kutanöz lezyonlarda artmış ${ }^{18} \mathrm{~F}-\mathrm{FDG}$ tutulumu gösterilmiş ve sol lateral alt uyluk bölge derisinden elde edilen biyopsi materyali ile SHK tanısı konulmuştur. On ay sonra yapılan ikinci PET/BT taraması sonucunda primer tümör alanı, sol inguinal ve sol supraklaviküler lenf nodu alanında artmış ${ }^{18} \mathrm{~F}$-FDG tutulumu gösterilmiştir. SHK'li DEB hastalarında ${ }^{18} \mathrm{~F}-\mathrm{FDG}$ PET/BT yönteminin özellikle uygun terapötik stratejinin belirlenmesi adına hastalığın yönetimi ve yeniden evrelendirilmesinde faydalı olacağı kanaatindeyiz.

Anahtar kelimeler: ${ }^{18}$ FDG-PET/BT, distrofik epidermolizis bülloza, skuamöz hücreli karsinom

Address for Correspondence: Esra Arslan MD, University of Health Sciences, İstanbul Training and Research Hospital, Clinic of Nuclear Medicine, İstanbul, Turkey Phone: +90 2124596455 E-mail: dresraarslan@gmail.com ORCID ID: orcid.org/0000-0002-9222-8883

Received: 21.07.2018 Accepted: 12.11.2018

${ }^{\circ}$ Copyright 2019 by Turkish Society of Nuclear Medicine

Molecular Imaging and Radionuclide Therapy published by Galenos Yayınevi. 


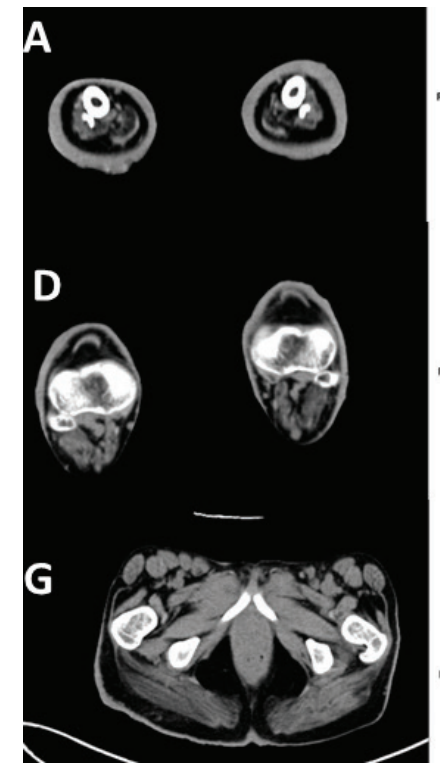

B

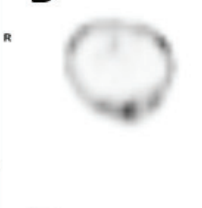

E

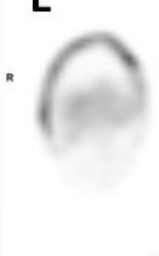

H
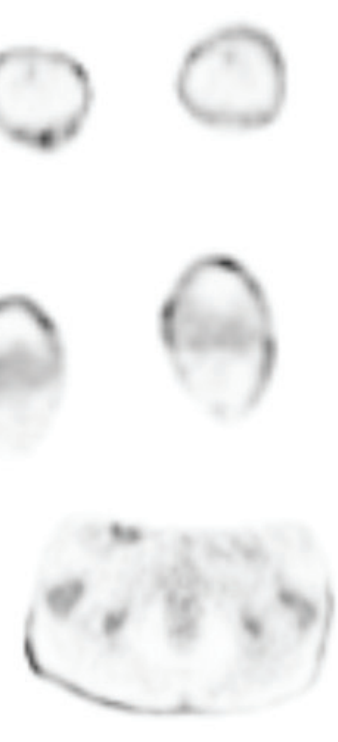

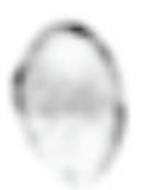

I

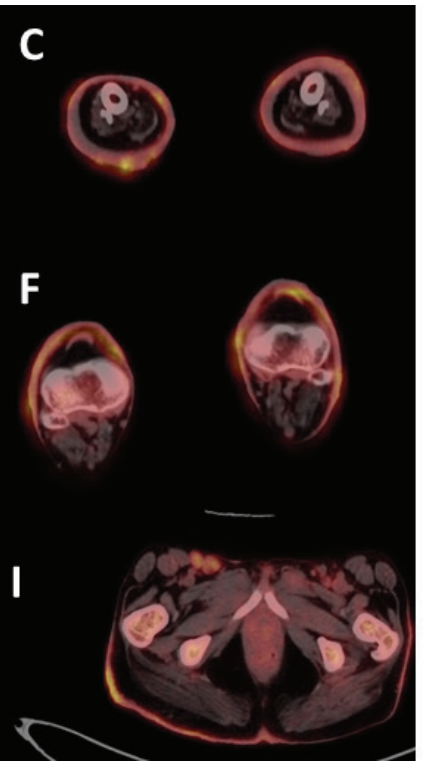

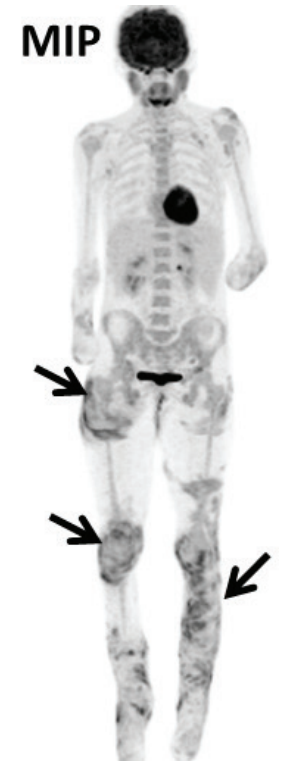

A, D, G: CT, B, E, H: PET, and C, F, I: Fusion slices. MIP: Maximum intensity projection

Figure 1. Epidermolysis bullosa (EB) is a clinically heterogeneous group of inherited blistering disorders characterized by increased skin fragility, while the dystrophic variant of $E B(D E B)$ is a clinically more severe subtype of $E B(1,2)$. Patients with $D E B$ are at high risk of developing squamous cell carcinoma (SCC), which particularly arise from areas of poorly healing wounds, and lead to metastasis and death (3). A 41-year-old female patient with DEB underwent ${ }^{18} \mathrm{~F}$-fluoro-2-deoxy-glucose positron emission tomography/computed tomography ( ${ }^{18} \mathrm{~F}$-FDG PET/CT) in the follow-up period. PET/ CT showed increased metabolic activity in multifocal cutaneous lesions in both lower extremities. The incisional biopsy performed from the skin of the left lateral lower thigh where one of the increased ${ }^{18} \mathrm{~F}-\mathrm{FDG}$ uptakes was observed revealed invasive SCC (black arrows). There was no other increased pathologic metabolic activity in any part of the skin, lymph nodes or organs 


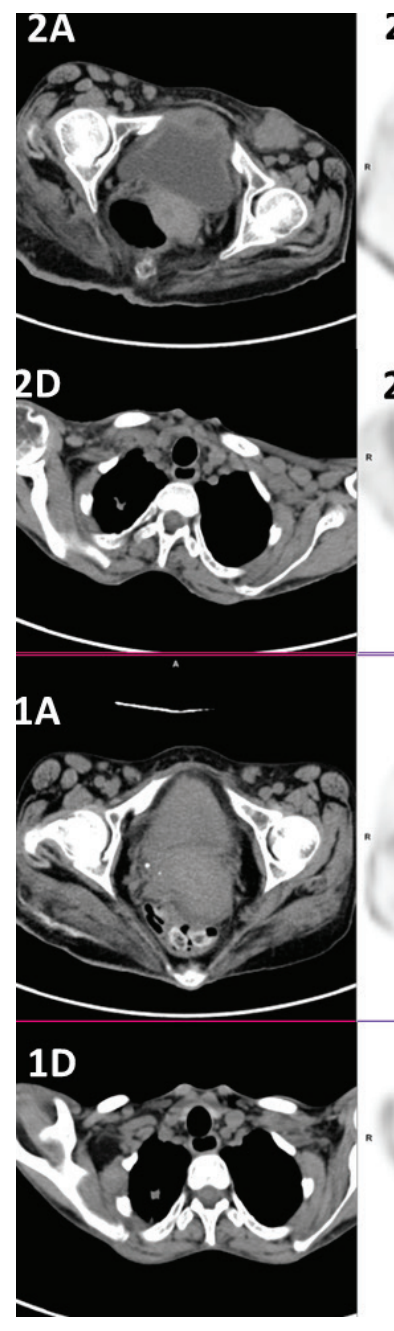

\section{B}

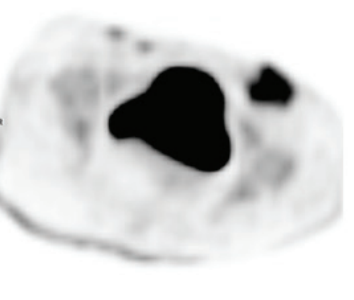

$2 E$

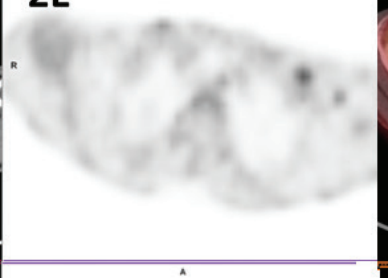

1B

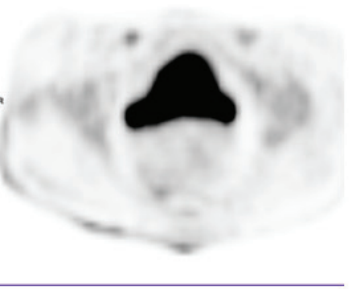

$1 E$
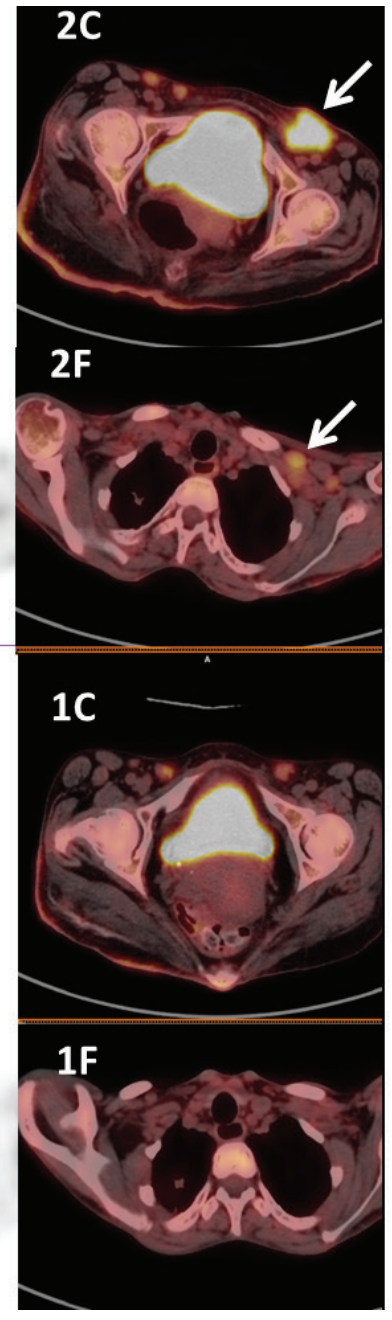

MIP

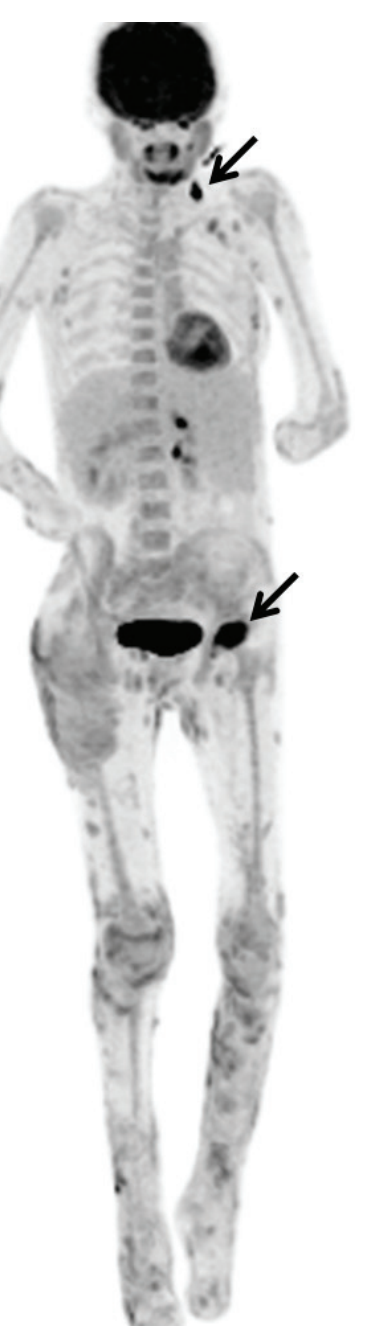

1: First PET/CT images, 2: Second PET/CT images. A, D: CT, B, E: PET and C, F: Fusion slices.

MIP: Maximum intensity projection

Figure 2. Ten months later, a second PET/CT scan was performed for re-staging purposes due to clinical detection of suspicious inguinal lymph nodes on physical examination. The second PET/CT showed a lymph node with increased FDG uptake in the left inguinal region (SUV ${ }_{\text {max }}$ 12.9) as well as additional unexpected lymph nodes in the left supraclavicular region (SUV max $_{11.0)}$ consistent with local and distant nodal metastasis (black arrows). Due to the multifocal or multiclonal onset of SCC, it is difficult to identify nodal and visceral spread of the tumor (4). Despite the high sensitivity of CT and PET/CT to detect subclinical nodal spread, false-positive results are still common. (5) By Jennings and Schmults $18 \mathrm{~F}-\mathrm{FDG}$ PET is reported to be beneficial to differentiate disease involvement and areas of necrosis and fibrosis. Cho et al. (6) have examined 12 SCC patients (nine cases with highrisk SCC) by ${ }^{18} \mathrm{~F}-\mathrm{FDG} / \mathrm{PET}$. The authors have identified lymph node metastases in three cases (25.0\%), distant organ involvement in one case (8.3\%) and primary lesions in nine cases (83.3\%). Mahajan et al. (7) reported that ${ }^{18} \mathrm{~F}-\mathrm{FDG}$ PET/CT achieved overall sensitivity and accuracy of $100 \%$ and $92 \%$, respectively, in 13 patients with primary SCC. It was emphasized that ${ }^{18} \mathrm{~F}-\mathrm{FDG}$ detected four previously unknown secondary lesions and changed management schedule in three of these. Supportively, Mackie and Avram (8) evaluated a 34-year-old woman with EB with soft tissue thickening in the left foot showing an increased ${ }^{18} \mathrm{~F}-\mathrm{FDG}$ uptake, which was confirmed histopathologically as SCC. In conclusion, ${ }^{18} \mathrm{~F}-\mathrm{FDG}$ PET/CT seems to be useful in re-staging and management of follow-up to plan appropriate therapeutic strategy in DEB patients with SCC 


\section{Ethics}

Informed Consent: Consent form was filled out by all participants.

Peer-review: Externally and internally peer-reviewed.

\section{Authorship Contributions}

Surgical and Medical Practices: E.A., T.F.Ç., A.E.K.A., M.S.G., C.L., Concept: E.A., T.F.Ç., A.E.K.A., M.S.G., C.L., Design: E.A., T.E.Ç., A.E.K.A., M.S.G., C.L., Data Collection or Processing: E.A., T.F.Ç., A.E.K.A., M.S.G., C.L., Analysis or Interpretation: E.A., T.F.C.., A.E.K.A., M.S.G., C.L., Literature Search: E.A., T.F.Ç., A.E.K.A., M.S.G., C.L., Writing: E.A., T.F.Ç., A.E.K.A., M.S.G., C.L.

Conflict of Interest: No conflict of interest was declared by the authors.

Financial Disclosure: The authors declared that this study received no financial support.

\section{References}

1. Schwieger-Briel A, Kiritsi D, Schempp C, Has C, Schumann H. BetulinBased Oleogel to Improve Wound Healing in Dystrophic Epidermolysis Bullosa: A Prospective Controlled Proof-of-Concept Study. Dermatol Res Pract 2017;2017:5068969.
2. Fine JD, Bruckner-Tuderman L, Eady RA, Bauer EA, Bauer JW, Has C, Heagerty A, Hintner $H$, Hovnanian A, Jonkman MF, Leigh I, Marinkovich MP, Martinez AE, McGrath JA, Mellerio JE, Moss C, Murrell DF, Shimizu H, Uitto J, Woodley D, Zambruno G. Inherited epidermolysis bullosa: Updated recommendations on diagnosis and classification. J Am Acad Dermatol 2014;70:1103-1126.

3. Montaudie H, Chiaverini C, Sbidian E, Charlesworth A, Lacour JP. Inherited epidermolysis bullosa and squamous cell carcinoma: a systematic review of 117 cases. Orphanet J Rare Dis 2016;11:117.

4. Stratigos A, Garbe C, Lebbe C, Malvehy J, del Marmol V, Pehamberger H, Peris K, Becker JC, Zalaudek I, Saiag P, Middleton MR, Bastholt L, Testori A, Grob JJ; European Dermatology Forum (EDF); European Association of Dermato-Oncology (EADO); European Organization for Research and Treatment of Cancer (EORTC). Diagnosis and treatment of invasive squamous cell carcinoma of the skin: European consensus-based interdisciplinary guideline. Eur J Cancer 2015;51:1989-2007.

5. Jennings $L$, Schmults $C D$. Management of high-risk cutaneous squamous cell carcinoma. J Clin Aesthet Dermatol 2010;3:39-48.

6. Cho SB, Chung WG, Yun M, Lee JD, Lee MG, Chung KY. Fluorodeoxyglucose positron emission tomography in cutaneous squamous cell carcinoma: retrospective analysis of 12 patients. Dermatol Surg 2005;31:446-447.

7. Mahajan S, Barker CA, Singh B, Pandit-Taskar N. Clinical value of 18F-FDG$\mathrm{PET} / \mathrm{CT}$ in staging cutaneous squamous cell carcinoma. Nucl Med Commun 2019.

8. Mackie GC, Avram AM. FDG PET imaging features of epidermolysis bullosa complicated by squamous cell carcinoma. Clin Nucl Med 2005;30:69-71. 